Historic, Archive Document

Do not assume content reflects current scientific knowledge, policies, or practices. 



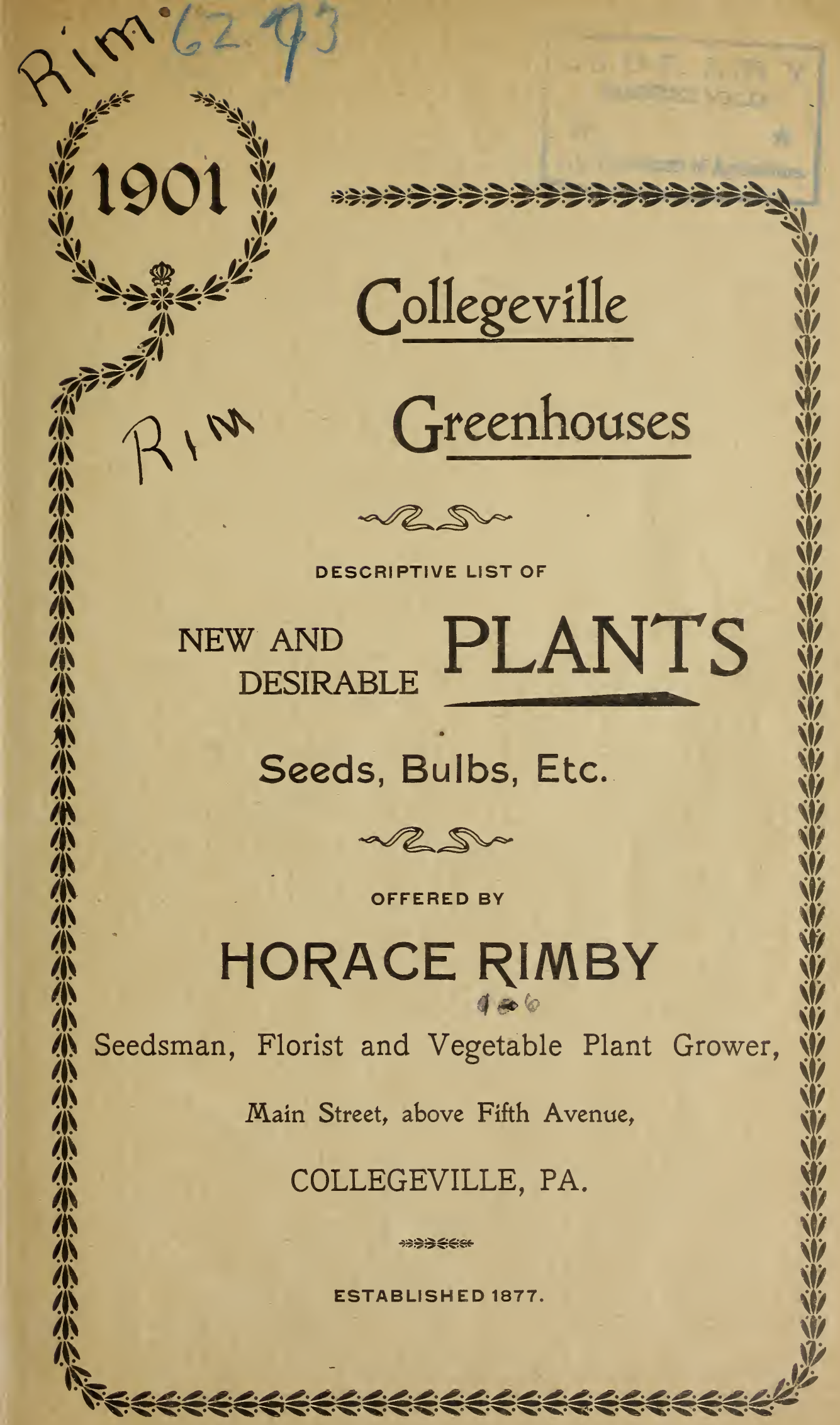




\section{Specialties $\left\{\begin{array}{l}\text { Geraniums, } \\ \text { Verbenas, } \\ \text { Roses, } \\ \text { Pansies, } \\ \text { Vegetable Plants. }\end{array}\right.$}

\section{Patrons and Friends :}

The most essential point in plant culture is to secure good strong plants. With the knowledge of this truth comes the demand for our plants that are wellknown for their vigorous growth. Our prices are not the lowest, as we do not attempt to compete with low priced grades, that never make any friends, but are as low as it is possible to grow PLANTS OF UNSURPASSED QUALITY. We give place in this price list only to plants and seeds of established merit, describe them honestly, and send them out in such a condition that they will grow for you, and please you We warrant all plants and seeds to be true to name.

These quotations are made subject to crop failures and to goods being unsold on receipt of order.

SEND ORDERS EARLY. Don't wait until the last of the season, when stocks are broken.

If plants are wanted by mail, always send sufficient money to cover postage.

We thank our many friends for their liberal patronage during the past year, and assure them that all orders entrusted to us. will receive our most careful attention.

If anything, not catalogued here, is wanted, write us at once, and if not in stock, we will procure the same at market price.

We would be pleased, at all times, to have our friends visit us, especially during MAY and JUNE for the SPRING SHOW, and NOVEMBER for the CHRYSANTHEMUM SHOW.

Our Greenhouses are located on Main street, above Fifth avenue Trolley cars from Norristown to Collegeville pass our greenhouses; cars sun every half hour. Only 7 minutes walk from the Perkiomen Railroad, Collegeville depot.

\section{HORACE RIMBY,}

\section{Seedsman, Florist and Vegetable Plant Grower, COLLEGEVILLE, PA.}

\section{TERMS : CASH WITH THE ORDER.}

Remit by P. O. Order, U. S. Express Order or Registered Letter.

No charge for packing aud delivering at depot.

Plants can be shipped by freight safely, after April, and money saved on excessive express (U. S.) charges.

No plants, etc., sent C. O. D.

We are not allowed to forward small packages by U. S. Parcel Express. So, when advisable, all orders will be shipped by freight, unless advised to the contrary.

We are human, and mistakes will occur, Should a mistake be made, we would be pleased to have our customers notify us at once, and we will cheerfully rectify the same.

If this price list does not interest you, please hand it to some lover of plants and oblige us. 


\section{Geraniums. (Our Specialty.)}

The Geranium heads the list of plants for free blooming, either for pots, or bedding out; not subject to disease; easy of culture; varied colors and the best and cheapest plant today.

The following new Geraniums are marvels of beauty, and surpass anything we have ever offered. They will surprise you. Try them. Come and see them in bloom after May 1st.

Prices quoted are for plants grown in $2 \frac{1}{2}$ in. pots.

\section{New Singles.}

Andrew Lang. Glowing scarlet, with large white blotch on the two upper petals, the centre suffused with carmine; the most brilliant contrast of colors yet found among the aureoles, united with a form nearly circular. Beds nicely. 25c.

Barbara Hope. Pale salmon pink, with white eye, shading off almost to white at the margin; a very large flower of almost perfect form and great substance; the plant has a spiendid habit, robust but dwarf, and produces flowers with wonderful freedom. 40c.

Clyde. A sport from Mrs. E. G. Hill, in cvery respect like its parent, except color, wirich is pure scarlet, of soft, even shade. Floret inmense, $2 \frac{1}{2}$ to 3 inches in diameter. Trusses I. to 16 inches in circumference. A grand bedder and also a fine pot plant. 20c.

Dorothy Burroughs. Delicate blush pink; a most lovely flower, reminding everyone who sees it of apple blosson; pips large, beautifully rounded, and of great substance. 30c.

De La Vigne. Enormous trusses, six to seven inches in diameter, held high above the foliage on stiff straight stems; color brilliant velvety red, shaded with bright orange scarlet, distinctly veined with deep maroon. This is altogether the nost brilliant color in geraniums that has yet been introduced; habit exceptionally strong and very vigorous; foliage disiinct and stands the sun perfectly. 25c.

Gen. Fitzhugh Lee. Very large florets of the showiest arrangement of white and crimson; a great advance on Renomme Lyonnaise, being a fine grower and standing the sun well. $35 \mathrm{c}$.

Hall Caine. Fine large trusses produced in great profusion, held high above the foliage; individual florets immense, $2 \frac{1}{2}$ to 3 inches in diameter; color bright cherry red, the habit is dwarf and compact, and exceptionally valuable as a pot plant. This is a striking flower, its telling color and immense size attracts universal attention; it is also a fine, vigorous grower. 20c.

Ian Maclaren. A very deep, warm shade of salmon, paler at the margin of the petals and deepening almost to orange at the centre, perfectly circular in outline and of wonderful substance, a grand flower in size; form and color. $25 \mathrm{c}$.
Jules Lemaitre. This variety is unapproachable for novelty and beauty. The floret is very large, and each petal is edged with bright pink, one-fourth inch wide; trusses grand. Very remarkable for its lasting qualities; a fine grower. 3oc.

Mark Twain. Ground color almost white, closely treckled and flaked with carmine, the color deepening at the margin of the petal to a rich lake, floret of fine shape. Very lasting for a single variety. $20 c$.

Mme. Charotte. This is one of the finest sorts of the Beaute Poitevine class; habit dwarf, very vigorous; the trusses are enormous and borne in the greatest profusion on fine foot stalks: the individual floret is very large and round, $2 \frac{\mathrm{I} / 2}{2}$ inches in diameter, semi-double; color clear, distinct rosy salmon; a splendid bloomer and a decided acquisition; unexcelled as a pot plant. $25 \mathrm{c}$.

Mme. J. Cibiel. Flowers of the very largest size, round and perfect, centre bright pink, white eye, large white border. Plant compact and free. Beautif:1, fresh color. Does finely indoors and out. 20c.

Mlle L. Moyot. A varicty with striped flowers. Very distinct from others of its class. Large white centre, borlered with vermillion. Very free, constant in bloom. 30c.

I1. P. Morlan. Plant very free, enormous trusses, large flowers of rosy salmon, centre white, surrounded by a halo of bright salmon. 25c.

Oliver. Another magnificent variety. The color of the flower is a bright, glowing scarlet, centre being pure white, suffused with rich magenta: habil vigorous, healthy and exceptionally floriferous. This is indeed a brilliant gem, and one of the brightest and most telling of all the varieties that have been raised from the new French strain; the habit is remarkably dwarf, compact and free. $25 \mathrm{c}$.

Pierre Le Brun. Enormous trusses, flower large, perfectly round. Color, deep rose, completely marbled and veined with a sable carmine, edge of petals very lively with brighter shades. 20c.

\section{New Doubles.}

Apotheose. Clear, bright rose color, with large white centre. The upper petals suffused with carmine. Habit grod. A very beautiful member of the double aureole family. $25 \mathrm{c}$. 
Emanuel Arene. One of the most startling novelties of the day. The floret is large and round, very fine, and of a pure rose color, with immense white eye. Both colors are very clear and pure, and are combined in the most showy way. ${ }_{5} \mathrm{C}$.

Hubert Charron. Clear white centre, with a heavy band of reddish carmine around each petal, maculated pure white. Fine habit; profuse bloomer. Unique, showy and striking. I $5 \mathrm{c}$.

J. B. Varonne. General color, carmine; centre, white, with shadings of rosy lilac. $20 \mathrm{c}$.

Jean Viaud. Ver̃y large semi-double blooms borne in large trusses well above the foliage; individual floret large; color bright rosy pink with distinct white blotch in the centre; habit dwarf, compact, very vigorous and exceptionally free blooming; probably the best pink geranium for bedding yet introduced. $20 \mathrm{c}$.

Kleber. Deep violet of velvety texture. Form of floret very fine. A free grower, and very free in bloom. 2nc.

La Fraicheur. Quite double, pure snowwhite, distinct narrow Picotee, edge of clear rosy pink. The effect is especially fresh and delightful. Dwarf, compact, very vigorous grower and an abundant bloomer. 20c.

La Fayette. Large, spherical trusses; color deep violet crimson; dwarf habit; fine compact grower; one of the most profuse bloomers of all; a magnificent variety. 20c.

M. H. Tilmant. Brilliant carmine pink, with distinct white blotch in centre, upper petals veined and shaded with rosy carmine; border of petal distinctly shaded with scarlet individual floret, very large, truss large, held well above the foliage; habit very strong and vigorous. One of the finest of the double aureole section. $20 c$.

M. Canovas. Imniense trusses of very dark, velvety scarlet, 'with dark crimson shadings. Flowers large, on rigid stems. A fine, free grower, and free in bloom. 20c.

Marquis de Castellane. (Bruant.) One of the most distinct and heautiful of recent introductions. Flowers perfect in form on large trusses; color bright cherry red, with brilliant carmine shading. Very profuse bloomer. 30c.

Pasteur. Cne of the most brilliant colors that we have in the scarlet section, being a bright orange scarlet, fully equal to Raspail Inıproved; truss is large. well formed; floret large semi-double; habit is dwarf, vigorous; exceptionally free in bloom. $25 \mathrm{c}$.

Richelieu. Large trusses formed of very large semi-double florets, crimson scarlet, with shadings of fiery scarlet. $20 \mathrm{c}$.

Rudyard Kipling. Fine dwarf, free-blooming habit; well shaped round bloom, $2 \frac{\mathrm{T}}{2}$ inches in diameter, of great substance; color rich crimson-purple or amaranth, with glowing crimson blotch at base of upper petals; a magnificent and striking variety. $20 \mathrm{c}$.

\section{Geraniums.}

\section{General Collection.}

\section{Single.}

Benjamin Schroder. Flowers extremely large, of soft rosy pink color, with distinct white blotch on the upper petals, of satiny texture. IOc.

Columbia. A splendid bedder; light, high scarlet of dazzling brightness, two upper petals white, shading to scarlet on the edges; extremely showy. IOc.

Dryden. A grand bedder, standing sun and rain better than any other of this type. It is a bright rosy red, with large white blotches on the two upper petals, and smaller blotches on the three lower ones, all five suffused with lake at the junction of the two colors. Dwarf, compact and very free. 20c.

Gettysburg. Bright crimson maroon of beautiful shade; fiower very large and of fine form. An extra beautíul dark variety. IOc.

Herrick. Rich glowing scarlet, with slight crimson shadings on the upper petals and distinct veins of maroon; individual florets exceptionally large size and good substance; habit is very good, being dwarf, compact and exceprionally floriferous. I5c.

John P•Cleary. Enormous trusses, composed of immense, round, individual florets; color a most brilliant shade of deep orange scarlet, with distinct maroon eye and upper petals distinctly veined with maroon; color so brilliant as to completely dazzle the eye; this is the freest blooming single scarlet geranium that we have had upon our place for many years. I5c.

Lady Brooke. Color, white and delicate pink mark in centre; very striking, trusses of fine size. Adnired by all who have seen it. IOC.

L'Aube. A grand single white bedding variety, with enorinous trusses of large, round flowers of good substance that do not burn in the hottest sun. 10c.

Mme. De La Roux. Clear, bright salmon; large trusses borne well above foliage; one of the finest bloomers that we have ever grown; habit diwarf; compact, vigorous. I5c.

Mrs. D'Ombrain. Pale blush at the margin, deepening to rich salmon at the centre; an immense flower; good habit and free flowering. Ve1 y perfect. Isc.

Mme. Coralie Bajac. Hias very fine trusses; the centre of the floret is white, the five petals regularly bordered with rosy carmine, which insensibly shades into pale violet before touching the white: free in bloom to the last degree. I5c. 
Mme. Bruant. White veined with carmine lake, the five petals regularly bordered in bright solferino: the arrangement of color is exquisite. IOc.

Mon. P. Olombel. Brilliant vermilion scarlet with orange shadings, trusses of immense size and perfe:t form, plant of the finest habit Too much cannot be said in praise of this sort for bedding.

Mrs. E. G. Hill. Florets $2^{1 / 2} \times 2$ inches. The centre of each petal is a soft light salmon, bordered with rosy salmon and veined deep rose.

Mrs. J. M. Gaar. Of dwarf, compact habit; and in freedom of bloom is superior to all whites.

Renommee Lyonaise. Glowing rosy scarlet with white eye and large white blotches on the upper petals; the flower is quite circular, and is dazzling beyond description. 20c.

St. Cecilia. A warm shade of salmon deepening toward the centre. The flower is large, both in pip and triss, and the plant is remarkably free flowering. Ioc.

Tippecanoe. Bright salmon scarlet; good sized truss on long stems; very full in bloom; lasts well in full sunlight; a very effective color among bedders.

\section{Geraniums.}

\section{Double.}

Alphonse Ricard. A strong grower, dwarf and branching and producing flowers in great masses. Both floret and truss are of enor1rous size, single or slightly doubled, and color a brilliant shade of orange red. IOc.

Beaute Poitevine. Very large florets of the most beautiful and distinct form and borne in immense trusses, very free bloomer, and as a hedder it has no equal in its color; brilliant salmon, brighter at the edges.

Bruant. Flowers light vermilion-red of a niost pleasing shade. Trusses exceptionally large.

Chaplin. Flowers large and round, brilliant scarlet with white centre. A grand dwarf variety for massing.

Francois Maynard. Crimson maroon, marked fiery red at the base of the upper petals; a variety remarkable for its deep color. Ioc.

Glori de France. A peerless variety, of a waxy salmon-white color, with a dark cinnamon-red centre; large finely formed trusses, borne well above the foliage. Ioc.

John Doyle. Color is of the richest scarlet, exceptionaly bright and effective, one of the most profuse blooming bedders that we have ever had; the habit is ideal; the foliage very broad and strong and stands the sun better than almost any other geranium we grow .I5c.

La Favorite. A singularly good double white.

La Pilot. Glowing crimson-scarlet; an elesant bedder.
Mad. Rozaine. Snow white. Strong, vigorous grower. Extra large trusses produced abundantly and held well above foliage. Individual florets very large. Probably the best double white bedder, as well as a first-class pot plant. Ioc.

Marvel. Dark red; the largest and finest of the S. A. Nutt class; floret a model of fine size and form. IOc.

Mary Hill. Rich, deep pink of the purest shade.

Mme. Ch. Dabouche Color, bright rose, shading to apple bloom pink. A superb variety.

Mme. Landry. One of the choicest and most beautiful yet added to the Bruanti type. Very free and constant in bloom throughout the season; trusses large, and florets of the tinest size and circular in form; color clear salmon, centre shading to copper, with a white eye. Very distinct and effective. I5c.

Mme. T. Noisette. Very rigid footstalks, with grand trusses and florets of a magnificent new color-rosy peach shading to orange at the centre; a superb variety and very free flowering. I5c.

Marquese de Montmort. Deep brilliant carmine-purple. One of the most novel and striking shades yet seen. A splendid habit, vigorous and clean. Excellent grower and profuse bloomer. Fine large floret, massive truss, held well up and erect. 20c.

Miss Frances Perkins. A charming shade of bright pink, fine large bloom and truss, licid well upon erect footstalks; vigoruus ilavit, profuse bloomer; stands our climate weil, and is a mass of color the seasun through!; 1:11surinases! as a pink bedder. I5c.

Prof. Poirault. Florets large and of brilliant violet color, the upper petals very distinctly marked with orange.

Raspail Improved. Intense pure scarlet, enormous semi-double floret, $2 \frac{\mathrm{T}}{2}$ inches in diameter, very round and regular; fine dwarf, compact habit; a magnificent winter bloomer; in fact, is a perpetual and profuse bloomer at all seasons: the grandest scarlet for pot culture: nothing to equal it. I5c.

Ryecroft Pride. One of the best double crimsons we have had; very large floret, 2 inches in diameter, borne in large fine trusses: color a pure crimson, upper petals shaded bright scarlet; habit compact, dwarf, vigorotis and healthy. I5c.

Thomas Meehan. Extremely large trusses and large florets; almost circular in form; brilliant rosy pink, the base of the upper petals marked orange: a noteworthy variety. I.5c.

Vera Vend. A "panache" variety, hard to describe-principally noted for its odd color, the truss and florets are both of good size; the shades are red, white and orange, marbled together. Habit and foliage very good. r. 5 c. 
William Pfitzer. Plant dwarf and compact, very free. Flowers in good size trusses. Color, clear orange salmon, distinctly edged white.

Prices, 7c. each; 75c. per doz.; except where noted.

We will have a fine stock of geraniums suitable for bedding out, in 3 in. pots, at $\$ 1.00$ per doz.; $33 / 4$ in. at $\$ 1.25$ per doz.; 4 in., at $\$ 1.50$ per doz. Plants readv May 1 st.

Special price quoted on large. quantity.

\section{Variegated Leaved Geraniums.}

Happy Thought. Large yellow blotcil iil centre of leaf, margined by an outer hand if green. IOc.

Mrs. George Foust. Bronzy zone of chocciate on golden yellow ground. I5c.

Mrs. Parker. Foliage deep green, with brcad, pure, snow-white band. Flowers duu bie, of an exquisite shade of deep, rosy pink, IOC.

\section{Pelargoniums.}

\section{(Lady Washington.)}

Dorothy. Flowers large; rosy salmum, dark: maroon blotched on upper petal, richiy shaded plum color around the throat; begins to flcwer early in the season and is covered with bloom to the end. 20c.

Madame Thibaut. White, richiy blotched and marked with rose, the upper petals markea with crimson maroon with large white centre. I5C.

Mrs, Robert Sandiford. A grand pure white sort; the flowers are very large, with fineiy I uificu edges, giving the whole flower the appearance of being doubled; a free bloomer. Ijc.

\section{New Ageratum.}

Stella Gurney. A strong compact grower, and very free blooming. Color is most intense blue. Is useful for edging geranium beds. IOc.

\section{Begonias.} ties:

W Ve can supply the following choice varic-

\section{Argenta Guttata.}

Erfordii. Paul Bruant.

Pres. Carnot, Metallica.

Vulcan and Thurstonii. each.

Price, $2 \frac{1}{2}$ in. pots, IOc; 3 in. pots, $15 \mathrm{C}$.

Rex Begonias. A fine assortment of these beautiful leaved plants. I $5 \mathrm{C}$ to $25 \mathrm{c}$.

\section{Cannas.}

All established in pots, ready May $\mathrm{I}$.

Alphonse Bouvier. Deep crimson, large t1uss, tall grower, one of the best. I5c.

Florence Vaughan. Yellow, spotted with crimson, one of the best. I5c.

Gloriosa. Rich scarlet-crimson, with broad bauc of yellow margin; an exceedingly free blooming variety, with very large truss; the plants average 2 feet in height; an exceeding y file iariety. I5c.

President McKinley. Brilliant crimson, scarlet shading. Truss large, compact, standing weil above the foliage; a very iree and continuous bloomer, bright glossy green foi. iage; $3 \mathrm{ft}$. $20 \mathrm{c}$

\section{Carnations.}

Daybreak. A very exquisite light pink.

Flora Hill. A grand white; very tree irs tioom.

Lilly Dean. A very large, bold, handsome flower, pure white ground, with very delicate ma1sin and penciling of clear pink, making it cxccedingly beautiful and attractive. IOc.

Mayor Pingree. Color, clear lemon yeilow, lightly marked with pink and occasionally splashed with white. IOc.

Melba. Light pink, free bloomer, strong growcr. IOc.

Peachblow. Fine pink, heavy petals, strong grower and free bloomer. Ioc.

Portia. The finest scarlet and most pruductsve of 1 ts class.

White Cloud. Strong gruwer; pure white. iOc.

Wm. Scott. A rich pink, habit oi growth strong, long stiff stems, early and very free.

Price, $7 \mathrm{c}$. eacli; 4 for $25 \mathrm{c}$. Except where noted.

\section{Chrysanthemums}

Autumn Glory. Deep pink, very large.

Diana. Dwarf white, pompon.

Geo. W. Childs. Deep crimson, fine.

Golden Wedding. Clear yellow, extra large.

Ivory. White, dwarf and good for all purpuses.

Kioto. Chrome yellow, incurved.

Major Bonnaffon. Soft yellow, incurved.

Merry Christmas. Pure wlite and the iatest kilown variety.

Niveus. One of the best late whites.

Solar Queen. Pale lemon-yellow; a very large bold handsome flower.

The Queen. White, extra large and ine.

W. H. Chadwick. White with a faint biusin of pink; a very large handsome incur ved flower.

W. H. Lincoln. Deep yellow, late.

Frice, roc. each; 3 for $25 \mathrm{c}$. except where noted. 


\section{Dahlias.}

A. D. Livoni. Soft, clear pink, fine.

C. W. Bruton. Rich pure yellow.

Wm. Agnew. Intense dazzling red.

Snowclad. Pure white pompon.

Miss May Loomis. Pure white, shaded lavencier.

Price, $20 \mathrm{c}$ each.

\section{Roses.}

\section{Best Out-Door Bedding Roses for Summer Blooming.}

Bon Silene. Carmine rose, very sweet.

C. Soupert. White, pink centre, very fine, úrible.

C. La Barthe. Light rose, shaded amber.

Crimson Rambler (Cliniber). Rich crinison. fine.

Etoile De Lyon. Best out-door yellow, very iree, double.

Golden Gate. Creamy white, centre rose.

Gruss An Teplitz. Scarlet, shading to velvety-crimson, fine. $20 c$.

Hermosa. Pink, free, double.

La France. Silvery rose, large, double.

Marie Guillot. Best out-door white, large; free, ciouble.

Marie Van Houtte (Gem). Straw yellow, edge of petals rosy-crimson.

Mad. Jos. Schwartz. Light rosy-pink, centïe creamy white.

Mad. Lambard. Rosy-bronze, salmon and fawis.

Meteor. Glowing crimson, very doublc.

Mad. Welche. Apricot yellow, large, duuble.

Maman Cochet. Bright rose, centre yel low, fine, double.

Mosella. White, with yellow centre, very free, double.

Papa Gontier. Rich red, long buds, frec.

Perle Des Jardins. Canary yellow, large, doubie.

Pres. Carnot. White, centre pink, large, double.

Souv. De Wooten. Double red, sweet I5c.

7. 0 Or roses have given excellent satisfaction, as our increased sales testify. They are all on their own roots. We do not wash, or shake off the soil before shipping, thereby retarding growth. If in doubt what kinds to select, leave it to us, and we know you will be pleased.

Prices: 3 in. pots, in April, I2c. each, Io for $\$ 1.00$; in May, $15 \mathrm{c}$. each, Io for $\$ 1.20$; in June, $20 \mathrm{c}$. each, Io for $\$$ I.5O, except where noted.

\section{Verbenas.}

Named varieties that are noted for their large size of flowers, freedom of bloom and beautiful colors; far superior to seedings.

Antonio. Deep blue, extra.

Beauty of Oxford. Dark pink, very fine. Climaxer. Extra large scarlet.

Dawn. Dark pink.

Francis. Pink, extra fine.

Mrs. Cleveland. Pure white.

Perfection. Solid pink.

Shakespeare. Large purple, white eyt.

Swanger's Beauty. Fine striped variety.

Willie Desmond. Bright scarlet, white eyє.

Price, 7 c. each; 4 for 25 c.

\section{Pansies.}

\section{Rimby's Prize Exhibition.}

Uur pansies are noted for their large size, heavy texture and brilliancy of colors. We hdie grown an extra quantity for our trade, this season.

Pansies should be planted early to secure best results.

I'rice, 5c. each; joc. per doz.; \$4.00 per roo.

\section{Condensed List of Plants, Etc.}

Ageratum, Princess Pauline, (new). "White and blue.

Alyssum, Dwarf and double.

Alternantheras, 2 kinds for borders, etc.

Anthericum Picturatum, I5c. to $25 \mathrm{c}$.

Azaleas, Assorted, 75c. to \$1.50.

Asparagus Sprengeri, I5c. to $50 \mathrm{c}$. "6 Plumosus, I $5 \mathrm{c}$. to $50 \mathrm{c}$.

Araucaria Excelsa, (Norfolk Island Pine), $\$ 1$ to $\$ 3.50$.

Browallia Gigantea, (new) 20c.

Callas, Hali dwarf, 25c.

Cannas, Assorted, I5c. to 25c.

Cyclamen, Assorted, 25c. to $50 \mathrm{c}$.

Cyperus Alternifolius, (Umbrella Plant), 15c. to $25 \mathrm{c}$.

Coleus, Assorted, for bedding, etc.

Coreopsis Lanceolata, hardy yellow floweis, $15 \mathrm{C}$. to $25 \mathrm{c}$.

Dahlias, Assorted, 20c.

Daisy, Etoile De Lyon (yellow) fine, $15 \mathrm{c}$. to $25 \mathrm{C}$.

Ficus Elastica, (Rubber, tree) 50c. to \$1.50.

“ “ Variegata, \$1.50.

Ferns, Boston and Dwarf Sword, Ioc. to $50 \mathrm{c}$.

Fuchsias, Single and Double, Ioc. to $25 \mathrm{c}$.

Gladiolus, Assorted, 25c. per doz.

Gaillardia, Superba, hardy, 50c. to $75 \mathrm{c}$.

Hydrangea, Pan. Grand, hardy, 50c. to $\$ 1.00$.

Harrisi, (Easter) Lily, 25c. to $75 \mathrm{c}$.

Heliotrope, Assorted, IOc. to $20 \mathrm{c}$. 
Impatiens Sultana, IOc.

Ivy, Parlor.

Lobelia, Blue, for vases, etc.

Moon Vines, I5c. to $20 \mathrm{c}$.

Nasturtium, Phoebe, new, tall, roc. Dwarf and tall mixed.

Othonna Crassifolia, (Pickle plant).

Palms, in variety, 25c. to $\$ 1.50$.

Pandanus Veitchi, (screw pine), $\$ 1.00$ to $\$ 2.50$.

Petunias, Double, fine, $15 \mathrm{c}$. to $25 \mathrm{c}$.

Single, dwarf and giant.

Pyrethrum, for edging.

Primroses, Ready Sep., Ioc.

Phlox, Assorted.

Primula Forbesi, (Baby Primrose), I5c. to $25 \mathrm{c}$.
Russellia Elegantissima, for vases, etc., r5c.

"Multiflora, for vases, etc., I5c.

Salvia, (Scarlet Sage), Dwarf, roc. to I5c.

Swainsonia Gal. Alba., I5c. to $25 \mathrm{c}$.

Thunbergia, Assorted.

Selaginella Emiliana, 8c. to I5c.

Tuberose Bulbs, Dw.arf Pearl.

Tradescantia, (Air plant).

Tropaecolum, Phoeke, new, fine, roc.

Vinca, (Periwinkle), variegated, Ioc. to I5c.

Violets, Princess of Wales, single, deep blue, roc.

Violets, Marie Louise, double, light blue, IOc.

Frice, 5c. each; joc. per doz., except where noted.

\section{Vegetable Plants Our Specialty.}

Thrifty Plants, well rooted, grown from the Best strains of Seeds obtainable, which can be depended upon for purity and excellence, thoroughly hardened, true to name, freshly dug and packed to ship long distances, are advantages secured to those who patronize this department of our business. As regards prices, you will find they are as low as good, healthy stocky, plants can be grown for. If any one quotes them lower, quality being equal, we will meet the same price.

\section{Beets.}

\section{Ready May Ist.}

Early Eclipse, Intense red; rapid growti best early.

6c. per doz.; 40c. per 100.

Blood Turnip, (Edmunds). Dark red, turnip shaped; best for winter.

6c. per doz.; 30c. per Ioo.

\section{Cabbage.}

Transplanted Early-Ready April ist.

跟 To grow cabbage successfully, plant on rich soil, never in the same place 2 years in succession; cultivate often; use slug shot for worms.

Earliest. Pointed head; two weeks earlicr than any other cabbage.

Jersey Wakefield. Pointed and round; sure header, later than above.

All-Head Early The earliest of all large head cabbages. Heads are deep, flat, remarkably solid and uniform in color; very tender, can be planted closer than the general ¡uil of cabbages, as it has fewer outer leaves.

Frice, Ioc. per doz.; 65 c. per Io0; $\$ 5.00$ per ICCO.

\section{Late Cabbage, Ready June Ist.}

Large Late Flat Dutch. Short stems, and large solid heads.

Sure Head. A very reliable header, large, round flattened heads of the flat Dutch typc; a good keeper and shipper, exceedingly populâr.

Short Stem Drumhead. The plants are so dwari that the heads appear to rest on the surface of the soil. Heads extra hard and solid; uniform in size, and all mature at the same time. Heads large and of the fincst quality.

$3 \mathrm{Cc}$. per 100; $\$ 2.00$ per 1000 .

Transplanted Plants are far superior to seed bed plants. Stronger, better rooted and produce earlier. 
Cauliflower.

Transplanted-Ready May Ist.

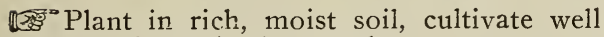
and water freely in dry weather.

Early Snowball. Very early and reliable header. 20c. per doz.; \$1.50 per 100.

\section{Celery.}

\section{Ready July Ist.}

258 Celery needs ricl ground and plenty of water in áry weather. Plant in shallow trenches, or on the level, 6 in. apart in the row, and the rows $3 \mathrm{ft}$. for dwarf, and $4 \mathrm{ft}$. apart for taller varieties. Hill up as the plants grow; never cover the heart. Celery is noted as an excellent nerve stimulant.

Improved Golden Heart. The best of the half-dwarf varieties, stalks large and full; the heart is golden yellow, turning to a light color when bleached. Very solid, rich flavor and a good keeper.

Giant Pascal. A superior keeping sort. The stalks are very large, thick, solid crisp, and of rich nutty Havor: it blanches very easily and quickly, and retains its freshness a long time.

White Plume. For Fall and early Winter use this is the most popular celery. The heart and stalk is naturally white, consequently requires very little blanching to be fit for the table. Its eating qualities are equal to the very best of the older sorts, being crisp, solid and of a pleasing nutty flavor, while its white feather like foliage places it ahead of all others as a table ornament.

Fin de Siecle. A white stalked variety of choice flavor. Highly recommended as a strong grower and fine winter keeper.

Shumacher. This is one of the most popular celeries in New York markets, many growers there regarding it one of the best winter varieties. Grows to a large size, with golden yellow heart, very solid and crisp.

30c. per 100; $\$ 2.00$ per 1000 .

We grow over 250,000 Celery Plants, cultivated and topped, every year. and supply some of the leading seedsmen of Philadelphia with our plants. Special prices quoted on large orders.

\section{Egg Plants.}

\section{Transplanted-Ready May Ist.}

Put a shovelful of well rotted manure in the place where you plant, and water in dry weather.

New York Improved Purple. Large size and very productive.

25c. per doz.: \$1.7.5 per hundred.

\section{Pepper.}

\section{Transplanted-Ready May Ist.}

Ruby King. Finest large ruby-red pepper grown; very mild.
Golden King. The beautiful and healthy plants bear large, handsome fruits, a most attractive bright golden yellow, which shine out of the rich dark-green foliage. The flavor is unsurpassed by any, exquisitely mild and pleasant.

Price, I8c. per doz., \$I.0o per hundred.

\section{Lettuce.}

Ready April Ist.

Bloomsdale Butter. Fine heads of large size. 6c. per doz., 40c. per hundred.

\section{Sweet Potatoes.}

\section{Ready May 15th.}

Our Sweet Potato Plants are becoming well known for their healthy, stocky appearance, and the great productiveness of the plants. The seed used is of the very best strain obtainable.

Plant on ridges, $3 \frac{1}{2} \mathrm{ft}$. apart, and $\mathrm{I}_{5}$ in. to 18 in. apart in the rows. Keep vines loose. Take up before severe frost and store in barrels, in warm place.

Yellow Nansenmond, 2.5c. per I00; $\$ 2.00$ per 1000 .

Red Nansenmond, 30c. per I00; \$2.50 per I000.

\section{Tomatoes.}

\section{Transplanted.}

\section{Ready about May Ist.}

Tomatoes do not want too much manure, as it will make them grow into vine, and the quaritity of fruit will be lessened. Plant $4 \mathrm{ft}$. by $6 \mathrm{ft}$. for tall growing, and $3 \mathrm{ft}$. by $4 \mathrm{ft}$. for divarf varieties.

"Magnus." This very distinct and most promising new variety, is the latest addition by Livingston to the Tomato family. The most handsorie sort in cultivation.

It is unsurpassed in quality, and in the production of fine, large fruits. While perfectly adapted to main crop planting, yet it matures so quickly that it will take first rank for early market.

The form is perfect, uniform, large and attractive. Flesh is very firm. It is a robust grower, with short joints, setting its fruit clusters closer together than most varieties, and is therefore a heavy cropper. The fruits are very deep from stem to blossom end. many of then being almost globe shaped. It ripens evenly, does not crack about the stem, and the flavor is most desirable.

20c. per doz.; \$1.25 per IOO.

Dwarf Golden Champion. The large, handsome fruits are of a beautiful lemon yellow color, very soiid and of unusually fine flavor. Never before have we had a yellow Tomato that was so large, solid and fine flavored. 2c. each. 
Matchless. This is the standard main crop, bright-red variety, producing enormous crops of finest scarlet fruits. Tomatoes are large, deep through, smiooth and uniform; more solidly meaty, with iewer seeds than any other variety; always of the finest quality.

Dwarf Aristocrat. This fine variety in habit of growth and foliage resembles the Dwarf Champion, and might be taken for that popuiar variety were it not for the color of its beautiful rich. glossy red fruit, so much preferred by many to the purple or rose-colored sorts. In size, solidity, productiveness, smoothness and flaror it is up to the present high standard of excellence.

Trucker's Favorite. One of the largest toinatoes grown. Color, purplish red, very solid, firm flesh. a good keeper, and not subject to rot or crack on the vines. Ripens evenly to the stem, is a strong, healthy grower, not subject to rust, or blight, is an enormous cropper, and produces until the vines are killed by frost, holding its size exceedingly well until the last picking. Quality the very best, and for cooking and slicing purposes it cannot be excelled.

I5c. per doz.; \$I.00 per I00; \$7.00 per I000.

The Stone. Fruit very large, bright scarlet, very smooth, ripening evenly to the stem without a crack: exceedingly solid and firm flesher; one of the best.

I2c. per doz.: 75c. per I00; $\$ 6.00$ per 1000 .
THE BEST or nothing SUITS US. No inferior seeds or plants handled.

We want agents to sell our plants, etc., to whom a liberal commission will be paid.

To lower the cost of plants, etc , club together and buy in quantity.

We believe in liberal count. Try us.

We carry in stock many things not listed in our price list.

Send us a list of what you may need and we will return same, with price attached.

We will procure for our customers any seeds, plants, etc., not listed here, but quoted in other catalogues. Flease mention the firm offering articles wanted, price of same, with amount enclosed. and we will attend to it promptly.

We can supply all implements for the garden, etc. Come and see, or write us, before ordering.

\section{DESCRIPTIVE LIST OF VEGETABLE SEEDS FOR THIS SECTION.}

The Seeds offered below are of the very best quality, and the prices quoted are as low as what Good Seeds can be bought for. The crop of Peas and Beans this year is very short. There is no economy in buying cheap seeds. In seeds the best is always the cheapest. Poor seeds are dear at any price.

\section{Bush Beans, Green Pods.}

Burpee's Stringless Green Pod. The only stringless green pod Bush Bean in cultivation. Very early.

Pkt. Ioc.; Pint, 20c.; qt., 35c.

\section{Bush Beans, Wax Pods.}

Landreth's Scarlet. Pods long, half flat, golden wax, 35 days fr.om germination, very productive, seeds large and scarlet. A very showy sort and very excellent.

Wardwell's Kidney Wax. Pods long, flat, yellow wax; seeds white.

Improved Golden Wax. Thirty-five days, pods flat showy; a productive sort.

I/2 pt. IOC.; I pt., 20c.; I qt. 35c.

\section{Bush Lima Beans.}

Burpee's Bush Lima. A true bush form of the Large White Lima, requires no poles. Pkt. IOc.; pint, $20 \mathrm{c}$.

\section{Pole Beans.}

Rimby's Improved Large Lima. An early and very prolific bearer. The beans are very large and of superb flavor. The fruit sets in clinsters of four and five, with four to six beans in a pod. This is one of the best Limas either greell or dry. $1 / 2$ pt.. IOc.; I qt., $40 c$.

King of the Garden Lima. More prolific than the ordinary lima, bearing pods five to six inches long, in clusters of four and five, with five to six beans in a pod. $1 / 2$ pt., IOc., I qt., $40 \mathrm{c}$.

Golden Cluster. The pods are a beautiful golden-yellow color and of large size, averaging from seven to eight inches long, and three-fourths of an inch in width. Although the pods are quite flat, they are fleshy, absolutely stringless and very brittle, while their flavor is delicious. 1/2 pt., I5c.

Bean crop very short.

If ordered by mail, add $8 \mathrm{c}$. per pint and $\mathrm{I} 5 \mathrm{c}$. per quart, for postage 


\section{Table Beets.}

Eclipse. A half-round Extra Early Red varicty; most excellent.

Edmund's Blood Red. Deep blood flesh, oial in form.

Long Blood Red. Deep red flesh, large root, yrows all underground.

Half-Long Blood Ked. Very smooth shin, fine form; color, dark blood; exceılent keeper.

\section{Cabbage.}

For varieties and descriptions see cabbage, uncier Vegetable Plants.

\section{Carrots.}

Half-Long Coreless. Coreless, or same textuse throughout, color orange; an excelleitt sort.

\section{Celery.}

For varieties and descriptions see Celery, under Vegetable Plants.

\section{Cucumbers.}

Short Prolific Pickle. Vine very compact, picking 50 days from planting; very productive.

Jersey Pickle. Productive standard sort for salting as it holds its color better than most others.

Early White Spine. Good size, solid, hoiding its green color, fitting it for long shipments.

Gherkin or Burr. Used for pickling only; fruit oval, larger than a walnut, covered with spines.

\section{Corn---Table Sorts.}

Early Crosby. Seventy days; a very reliable early sort.

Country Gentleman. Very productive, grain very small, like Shoe Peg.

Landreth. Fit for table seventy-five days iivni gcrmination, exceedingly productive and better than any preceding, averaging 3 ears to the stalk. A standard sort of high reputation.

Evergreen. (Stowell's). Eighty-two days, productive, showy, always a standard.

It pt., 8c.; I pt., I2c.; I qt., $20 \mathrm{c}$.

If ordered by niail, add $8 \mathrm{c}$. per pt., I5c per Git., Sor postage.

\section{Fgg Plant.}

Landreth's Thornless Round Purple. This oiicn reaches a weight of twelve pounds. It is nearly round, and the vine is thornless.

\section{Endive.}

White Curlet. More delicate than the Gicen Curled, but requires bleaching.

\section{Herbs.}

Marjoram, Sweet. Leave used in flavoring.

Sage. Used in flavoring kitchen preparations.

\section{Lettuce.}

Early Curled Silesian. No head, loose leaves, golden yellow.

Speckled Dutch Butterhead. A long standing white heading variety.

Bloomsdale Early Summer. Yellow leaves, aiways heading, slow to shoot, a most superior sort; a most reliable family variety.

Bloomsdale Butter. A hardy dark green leaved heading sort, late.

\section{Watermelon.}

Dixie. A large chunky early variety.

Arkansas Traveler. Form long, almost black with lighter stripes, rind thin, flesh a brilliant scarlet, crystaline, melting sugary.

Boss. Black skin, form long, heavy, flavor unexcelled, flesh solid brilliant scarlet, crystaline, inelting.

\section{Cantaloupe.}

Extra Early Cape May. Early, good size, roundish, deeply ribbed; quality excellent.

Miller Cream or Osage. A remarkably goud variety, of large size and delicious flavor, flesh rich salmoll, very thick and solid.

Rocky Ford. One of the best early meio11s 11 existence for market gardeners and shippers, as well as for the home garden.

Emerald Gem. Small, early, productive; sweet salmon flesh.

\section{Onion.}

Bloomsdale Early Red. Broad, flat, deep rcci, very eariy.

Silverskin. An early flat sort, long cultivated at Philadelphia.

True Yellow Globe Danvers, Straw color, long keeping; oval in form, solid.

\section{Parsley.}

Emerald Gem. Deep green in color, double curled, short jointed and tufted.

\section{Parsnip.}

Bloomsdale. Best bred and handsomest to be found, a broad shouldered half-long hcavy.

\section{Peas.}

Landreth's Extra Early. The earliest pea in cultivation and the best flavored, maturing in about 48 to 50 days from germination.

Premium Gem. A strong growing form of Little Gem. 
Everbearing. A good pea for summer and autumn use, pods 4 inches long, and contain 6 to 8 peas of rich flavor, very sweet and tende1; 2 fect. 20c. pt.; 30c. qt.

Improved Stratagem. Wrinkled marrow, large size peas of excellent quality; $2 \frac{1}{2}$ feet high. 20c. pt.; 30c. qt.

Champion of England. One of the best and most popular wrinkled varieties in cultivation, of delicious flavor; a profuse bearer; five feet high.

Pride of the Market. A round, blue Pea. Certainly one of the best of the late introductions. Height of vine fifteen to eighteen inches. Pods of enormous size, borne nine to ten on a vine, and containing as many Peas in each pod. 20c. pt.; 35c. qt.

I/2 pt., IOc.; I pt., I5c.; I qt., 25c., except where noted.

if ordered by mail, add 8c. per pt.; 15c. per qt., for postage.

\section{Pumpkin.}

Yellow Cashaw. Yellow, crooked neck, sixly to eighty pounds, best for pies.

\section{Salsify.}

Sandwich Island. A thicker, shorter root than the French.

\section{Radish.}

Early Deep Scarlet. About 22 days to maturily, a scarlet half-round form.

Landreth's White Lady Finger. Twentyfour days to maturity, quick growing, a long, slim White; a great favorite, the only good loil's carly White.

Market Gardeners' Early Long Scariet Improvement on the old Long Scarlet, being bruader at top and not so long.

Early Long White Vienna. Half long, white all over and very crisp.

Scarlet China Winter. Half long stump, upjer half scarlet, lower half pink, flesh white, quick in growth.

\section{Spinach.}

Bloomsdale. The best autumn sort, so supuior that no other is comparable with it.

\section{Squash.}

Early White Bush or Patty Pan. The Cymbling, maturing 50 days from germination, flat; always white, young or old.

Golden Summer Crook Neck. Maturing 40 days from germination, hooked form, yeiluw, warty, a bush.

\section{Tomato.}

For varieties and description, see Tomato, under Vegetable Plants.

\section{Turnip.}

Large Early Red-Top Globe. Red crown, white bottom, round in shape, early.

All seeds are 5c. per paper, except where noted. Special prices on large quantities.

W We can supply all kinds of Farm Seeds.

\section{Large Flowering Sweet Peas.}

Eckford's Gilt Edge Large Flowering Mixed.

New varieties.

5c. and Ioc. per pkt.; 30c. $1 / 4 \mathrm{lb}$.

We can supply all varieties of flowering seeds.

Bulbs for Fall Planting.

(Ready in September.)

Hyacinths, Single and Double, Red, White and Blue.

Tulips, Single and Double, Superfine Mixed.

Harrisi (Easter), Lily.

Freesia, Refracta Alba.

Prices on application.

\section{Grass Seeds, Etc.}

Mixed Lawn Grass. Finest mixture; indispensible in producing a fine lawn. 20c. po1 qt.

White Dutch Clover. (Extra recleaned). Thie best variety for fine lawns. 35c. per $\mathrm{lb}$.

Timothy. (Extra recleaned). Extra clioice stock. 15c. per qt.

Slug Shot. The greatest insecticide yet introduced; sure death to insects, polato bugs, cabbage fly and worm, and excellent for henneries, to kill lice on chickens. $5 \mathrm{lbs}$., $25 \mathrm{c}$.

Rimby's Lawn Enricher. One of the best fertiiizers for lawns, gardens, roses, flowers. 5 livs., 25c.; $100 \mathrm{lbs}$., \$3.00. Try it.

Rimby's Plant Food. Specially preparcd for house plants, to produce healthy plants anci fine flowers. I5c. 1b.; 2 lbs. for $25 \mathrm{c}$.

Lawn Mowers. Philadelphia and Pennsylvania Lawn Mowers. Send for list and lowest quotations.

Tobacco Dust. Excellent for killing green fy on ruses, plants, etc. 5c. per qt.

Jersey Peat. For palms, etc. 5c. per gt.

Leaf Mold. Very useful for mixing with soils for begonias. 5c. per qt.

\section{Grape Vines.}

\section{Two Years Old Selected Vines.}

Concord. Early; black, juicy and sweet; anci berry large. 25c.

Niagara. Strong grower; bunches large and compact; light greenish-white; skin thin, but tuugh, and does not crack; quality good. 25c.

Empire State. White, fine flavored and productive; bunches large and shouldered. $25 \mathrm{c}$.

ilhe set of 3 for $65 \mathrm{c}$.

\section{Strawberries}

Catawissa. Clear red; very large, firm, sweet and of good quality; rapid and vigurous grower. Superior to the Sharpless. 25c. per doz.; \$1.50 per 100.

Brandywine. Medium to late; now recognized as a standard sort; large, dark red berry. suited to the table or to the preserving kettle. 25c. per doz.; \$1.25 per Ioo.

\section{CUT FLOWERS.}

We are prepared at all times to furnish cut flowers of the choicest varieties for all occasions, and will arrange them in the most artistic manner, on the shortest notice. Cut Flowers or Designs for Funerals, or other occasions, will be packed to carry safely by express. Orders by mail for the above will receive prompt attention. 